\title{
PENGEMBANGAN MODEL AGROEDUWISATA SEBAGAI IMPLEMENTASI PERTANIAN BERKELANJUTAN
}

\section{(Development of Agroedutourism Model as the Implementation of Sustainable Development)}

\author{
Nurul Dwi Novikarumsari ${ }^{1^{*}}$ dan Siti Amanah ${ }^{2}$ \\ ${ }^{1}$ Perhimpunan Ahli Penyuluhan Pembangunan Indonesia Sekretariat PS Pascasarjana Ilmu Penyuluhan \\ Pembangunan, Fakultas Ekologi Manusia, Institut Pertanian Bogor, Bogor 16680. \\ ${ }^{2}$ Departemen Komunikasi dan Pengembangan Masyarakat, Fakultas Ekologi Manusia, Institut Pertanian \\ Bogor, Bogor 16680 \\ *E-mai korespondensi: nurul_novika@apps.ipb.ac.id
}

Received: 1 October 2018; Revised: 27 March 2019; Accepted: 7 April 2019

\begin{abstract}
Abstrak
Dimensi sosial, lingkungan alam dan manusia merupakan aspek utama dalam pertanian berkelanjutan. Aspek lingkungan alam disediakan oleh kawan dan manusia mencakup subyek/pihak-pihak terkait memberikan peluang bagi pengembangan agroeduwisata sebagai salah satu upaya peningkatan ekonomi masyarakat. Penelitian ini bertujuan untuk menganalisis kebutuhan petani terkait penyuluhan dan menyusun model pengembangan agroeduwisata di lokasi penelitian. Penelitian ini dilaksanakan di empat wilayah Kota/Kabupaten Bogor, yaitu Kelurahan Cimahpar, Kelurahan Situgede, Desa Benteng dan Desa Purwasari. Penelitian ini menggunakan metode mix methods, data kuantitatif diperoleh dari 201 petani yang dipilih secara acak dan data kualitatif melalui Focus Group Discussion (FGD) dan wawancara mendalam. Hasil penelitian menunjukkan bahwa: 1) mayoritas petani (34,3\%) membutuhkan penyuluhan terkait budidaya, dan 2) setiap lokasi memiliki strategi model agroeduwisata bisa diterapkan di lokasi penelitian dengan pelibatan berbagai pihak (kelompok wanita tani, gabungan kelompok tani, dan kelompok lainnya).
\end{abstract}

Kata kunci : pertanian berkelanjutan, agroeduwisata, penyuluhan, kelompok tani, kelembagaan

\begin{abstract}
The social, natural and human environment are the main aspects of sustainable agriculture. Aspects of the natural environment provided by friends and humans including the subjects / related parties provide opportunities for the development of agro-tourism as an effort to improve the community's economy. This study aims to analyze the needs of farmers related to counseling and develop agro-tourism development models at the research location. This research was carried out in four Kota / Kabupaten districts, namely Cimahpar Village, Situgede Village, Benteng Village and Purwasari Village. This research uses mix methods, quantitative data were obtained from 201 randomly selected farmers and qualitative data through Focus Group Discussion (FGD) and in-depth interviews. The results showed that: 1) the majority of farmers (34.3\%) needed counseling related to cultivation, and 2) each location had an agro-tourism model strategy that could be applied at the study site with the involvement of various parties (farmer women's groups, farmer groups combined, and other groups.
\end{abstract}

Keywords: sustainable agriculture, agroedutourism, extension, farmer groups, institutions 


\section{PENDAHULUAN}

Pertanian berkelanjutan mengintegrasikan berbagai aspek sebagai suatu sistem. Aspekaspek yang berkaitan tersebut antara lain agronomi, ekologi, ekonomi, sosial dan budaya (Salikin, 2003). Lebih lanjut menurut Rival RS et al., (2011), pembangunan pertanian perdesaan yang berkelanjutan menjadi isu penting strategis yang menjadiperhatian dan pembicaraan semua negara dewasa ini. Pembangunan pertanian berkelanjutan selain sudah menjadi tujuan, tetapi juga sudah menjadi paradigma pola pembangunan pertanian.

Salah satu pengembangan dan penerapan pertanian berkelanjutan yaitu dengan adanya pengelolaan kawasan pertanian dan pengembangan pertanian dari sisi hulu hingga hilir. Integrated farming system yang mencakup berbagai subsektor pertanian ini memberikan peluang pengembangan agroeduwisata di berbagai daerah (Kusumastuti et al., 2018).

Bogor merupakan kawasan yang strategis karena lokasinya berdekatan dengan kota-kota yang tingkat kependudukannya cukup padat, seperti Jakarta, Bekasi, Depok, Tangerang, dan kota-kota lainnya sehingga mudah dijangkau oleh wisatawan. Rata-rata jumlah kunjungan wisatawan yang datang ke Bogor setiap tahunnya mengalami peningkatan (BPS Kota Bogor, 2018). Untuk itu, tujuan penelitian ini adalah: (1) untuk menganalisis kebutuhan petani terkait penyuluhan dan (2) menyusun model pengembangan agroeduwisata.

\section{METODE PENELITIAN}

Metode penelitian mix methode digunakan dalam penelitian ini. Data yang digunakan menggunakan data kuantitatif dan data kualitatif. Metode penelitian kombinasi (mixed methods) meupakan metode penelitian yang menggabungkan antara metode kuantitatif dan metode kualitatif untuk digunakan secara bersama-sama dalam suatu kegiatan penelitian sehingga diperoleh data yang lebih komprehensif, valid, reliabel dan objektif (Sugiyono, 2011).

Data kualitatif diperoleh dari indepth interview dan Focus Group Discussion (FGD) yang dilakukan, sedangkan data kuantitatif diperoleh dari 201 anggota kelompok tani/wanita tani yang dipilih secara acak di
Kota/Kabupaten Bogor sebagai berikut: sebanyak 29 orang di Kelurahan Situgede, 42orang di Kelurahan Cimahpar, 92 orang di Desa Purwasari dan 38 orang di Desa Benteng.

\section{HASIL DAN PEMBAHASAN}

Penelitian dilaksanakan di empat lokasi yang terdiri dari dua Kelurahan yaitu Kelurahan Cimahpar dan Kelurahan Situgede dan dua Desa yaitu Desa Benteng dan Desa Purwasari. Dari segi luasan lahan pertanian, Kelurahan Cimahpar memiliki lahan pertanian terluas yakni 369.5 ha dengan kepala keluarga terbanyak yaitu $3671 \mathrm{KK}$.

Mayoritas sumber mata pencaharian berbeda di masing-masing lokasi penelitian, di bidang pertanian paling banyak terdapat di Desa Purwasari sektor industri kerajinan rumah tangga paling banyak di Desa Benteng, berbeda dengan Kelurahan Cimahpar yang mayoritas penduduknya sebagai wiraswasta dan Kelurahan Situgede yang mayoritas penduduknya sebagai peternak.

Dari segi penghasilan rata-rata dari empat lokasi penelitian, berpenghasilan sebesar Rp 2148297.87 sedangkan penghasilan dari usaha tani sebesar Rp. 2107754.24 serta rata-rata kepemilikan lahan seluas 2846.93.

Masyarakat Desa Purwasari yang bermatapencaharian sebagai petani memiliki komoditas berbeda dengan petani di Kelurahan Cimahpar, beberapa komoditas petani di Desa Purwasari yaitu padi (luasan $56.15 \mathrm{ha}$ ), jagung (luasan $46.25 \mathrm{ha}$ ), ubi jalar (luasan 21.5 ha), dan Ubi Kayu (luasan 29.5ha), sedangkan petani di Kelurahan Cimahpar lebih banyak menanam sayuran dan buah seperti cabe ( $2 \mathrm{ha}$ ), umbi-umbian (10 ha), pepaya (10 ha) dan pisang (3 ha).

Dilihat dari kenggotaan dalam kelomok tani/kelompok wanita tani. Petani responden di empat wilayah penelitian mencakup responden dari duabelas Kelompok Tani/Wanita Tani (KWT/KT) di Kelurahan Cimahpar (Poktan Tani Jaya dan KWT Melati), Kelurahan Cimahpar (Poktan Saluyu, KWT Sawargi, dan KWT Geulis), Desa Benteng (Poktan Cahaya, KWT Puring, dan KWT Benteng Sejahtera), dan Desa Purwasari (Poktan Bina Mekarsari, Poktan Kramatsari, Poktan Hegarsari dan Poktan Rawasari). Kelompok Tani/Wanita Tani tersebut mengusahakan beragam jenis komoditas dan usaha olahan dalam Tabel 1. 
Tabel 1. Jenis Komoditas dan Usaha Olahan Berdasarkan Wilayah Penelitian dan Kelompok Tani/Wanita Tani

\begin{tabular}{|c|c|c|}
\hline $\begin{array}{l}\text { Wilayah } \\
\text { Penelitian }\end{array}$ & $\begin{array}{c}\text { Kelompok } \\
\text { Tani/Wanit } \\
\text { a Tani }\end{array}$ & $\begin{array}{c}\text { Jenis Komoditas/Usaha } \\
\text { Olahan }\end{array}$ \\
\hline $\begin{array}{l}\text { Kelurahan } \\
\text { Cimahpar }\end{array}$ & Poktan Jaya & $\begin{array}{l}\text { Singkong, papaya, ubi, } \\
\text { jahe merah, timun, } \\
\text { jagung, bengkoang } \\
\text { Manisan (papaya, salak, } \\
\text { pala, manga), kue basah, } \\
\text { warung, kue kering } \\
\text { (lebaran) }\end{array}$ \\
\hline $\begin{array}{l}\text { Kelurahan } \\
\text { Situgede }\end{array}$ & $\begin{array}{l}\text { Poktan } \\
\text { Saluyu } \\
\text { KWT } \\
\text { Sawargi } \\
\text { KWT Geulis }\end{array}$ & $\begin{array}{l}\text { Talas, bengkoang, } \\
\text { kacang Panjang, timun, } \\
\text { ikan hias } \\
\text { Coklat, dodol } \\
\text { Dendeng belut, warung }\end{array}$ \\
\hline $\begin{array}{l}\text { Desa } \\
\text { Benteng }\end{array}$ & $\begin{array}{l}\text { Poktan } \\
\text { Cahaya } \\
\text { KWT Puring } \\
\text { KWT } \\
\text { Benteng } \\
\text { Sejahtera } \\
\end{array}$ & $\begin{array}{l}\text { Toga, cabe, jahe merah, } \\
\text { papaya Jepang } \\
\text { Sebelumnya toga, } \\
\text { beralih ke pengolahan, } \\
\text { warung }\end{array}$ \\
\hline $\begin{array}{l}\text { Desa } \\
\text { Purwasari }\end{array}$ & $\begin{array}{l}\text { Poktan Bina } \\
\text { Mekarsari } \\
\text { Poktan } \\
\text { Kramatsari } \\
\text { Poktan } \\
\text { Hegarsari } \\
\text { Poktan } \\
\text { Rawasari }\end{array}$ & $\begin{array}{l}\text { Padi, katuk, kacang } \\
\text { panjang, kolam ikan } \\
\text { Pepaya, katuk, jagung, } \\
\text { kolam ikan, bengkoang } \\
\text { Ubi, kacang Panjang, } \\
\text { timun, jagung, singkong } \\
\text { Ubi, singkong, jagung, } \\
\text { kacang Panjang }\end{array}$ \\
\hline
\end{tabular}

Pada Tabel 1. tersebut bahwa secara umum kegiatan usahatani yang dilakukan oleh kelompok tani cenderung pada tanaman pangan, sayuran dan budidaya ikan. Sementara usahatani yang dilakukan oleh Kelompok Wanita Tani melakukan usaha pengolahan, seperti olahan makanan ringan dan budidaya tanaman toga. Pada Tabel 1. bahwa usaha komoditas olahan cenderung menjadi pilihan petani responden di wilayah kota, dibanding petani responden di wilayah Desa yang masih dominan melakukan usahatani dalam budidaya tanaman pangan dan sayuran.

Kebutuhan akan pekerjaan sampingan di bidang non pertanian karena sector pertanian memiliki tingkat kesulitan yang lebih tinggi. Kesulitan dalam bertani (Tabel 2) baik dari sisi pembiayaan, risiko gagal panen, dan harga jual yang rendah. Upaya peningkatan pemasaran dapat dilakukan melalui penjualan produk olahan dengan terlebih dahulu dilakukan pendampingan pelatihan pengolahan komoditas unggulan seperti di Kelurahan Situgede, produk dodol dan coklat talas menjadi unggulan sehingga dapat ditingkatkan pemasaran lebih lanjut.

Tabel 2. Jenis kesulitan yang dihadapi petani dalam menjalankan usaha pertanian

\begin{tabular}{|c|c|c|c|}
\hline No. & Jenis kesulitan & $\mathbf{n}$ & $\%$ \\
\hline \multirow{5}{*}{$\begin{array}{l}1 . \\
2 . \\
3 . \\
4 .\end{array}$} & harga saprodi & 21 & 10.4 \\
\hline & Hama & 31 & 15.4 \\
\hline & Musim & 15 & 7.5 \\
\hline & $\begin{array}{l}\text { harga jual } \\
\text { produk rendah }\end{array}$ & 50 & 24.9 \\
\hline & Total & 201 & 100.0 \\
\hline
\end{tabular}

Kendala utama yang dirasakan dalam menjalankan usaha pertanian yaitu harga jual hal ini terkait pasar, karena tidakadanya jaminan harga jual pada petani.

Banyak petani beralih ke palawija dan hortikultur karena merasa sedikit keuntungan yang didapat dari padi. Namun tidak ada harga pokok untuk palawija seperti harga padi yang dapat menjamin keuntungan petani. Tingkat kekompakkan kelompok tani berkurang disebabkan oleh pergantian penyuluh, usia petani semakin tua dan tidak ada regenerasi, distribusi bantuan yang tidak merata. Padi, jagung, kedelai (PAJALE) didukung oleh penyuluh, keuntungan padi dan palawija berkurang daripada hortikultur sehingga minat menanam padi semakin berkurang.Dinas pertanian tetap mendorong petani menanam padi sebagai bagian dari program nasional. Petani menanam padi karena diberikan bantuan dari dinas seperti benih, traktor, dan lainlain.Anggota kelompok banyak yang tidak aktif. Pendidikan petani sebagian besar lulusan SD yang memerlukan pendidikan non formal. Selain itu usia mereka di atas 40 tahun. Poin Sustainable Development Goals yang dapat disasar adalah pendidikan yang berkualitas bagi petani.Sebagian anggota keluarga juga masih banyak yang lulusan SD dan SMP.

Seperti halnya yang dikemukakan Argabright et al., (2012); Yanfika et al. (2019) dan Listiana et al. (2019), penyuluhan yang dilakukan merupakan proses kreatif dan inovatif, mengenali karakteristik budaya masyarakat setempat, dapat diaplikasikan dalam praktik sehari-hari yang memunculkan dan mendukung perilaku kreatif dan inovatif. Penyuluhan juga menumbuhkan lingkungan yang mendukung di mana stakeholder terbuka untuk ide-ide baru dan memiliki kesediaan untuk melindungi risiko saat fokus pada tujuan 
Nokiarumsari dan Amanah (2019): Dukungan kelembagaan eksternal terhadap penguatan Gapoktan

akhir. Beberapa contoh potensial dari proses kreatif dan inovatif dalam penyuluhan meliputi: menetapkan desain organisasi yang menggabungkan struktur pendanaan kompetitif internal dan eksternal yang mendorong upaya kewirausahaan. Selain masalah yang banyak dihadapi petani, peran kepala desa menjadi indikator penting dalam keberlanjutan pertanian di desa (Tabel 3).

Tabel 3. Peran kepala desa dalam mendukung pertanian

\begin{tabular}{llcc}
\hline No. & Peran & $\mathrm{N}$ & $\%$ \\
\hline 1. & Bantuan sarana & 1 & 8.0 \\
& prasarana fisik desa & 6 & \\
2. & Bantuan modal usaha, & 2 & 14.4 \\
& $\begin{array}{l}\text { subsidi } \\
\text { 3. }\end{array}$ & 9 & \\
& $\begin{array}{l}\text { Menunjang aktivitas sosial } \\
\text { (pemasaran, event, }\end{array}$ & 2 & 10.4 \\
pelatihan) & 1 & \\
4. & Memberikan solusi kepada & 5 & 28.9 \\
& petani/masyarakat & 8 & \\
5. & Penyaluran bantuan & 1 & 8.0 \\
\hline
\end{tabular}

Peran pemerintah desa, kepala desa, LPM, dan PKK dianggap masyarakat sebagai pemberi solusi dalam permasalahan yang dihadapi mulai dari permasalah kekurangan input, dan menggagas adanya pengembangan kawasan dengan agroeduwisata. Seperti halnya yang dikemukakan Fauziah et al., (2016), bahwa strategi pengembangan dan pengelolaan agroedutourism berkelanjutan dilakukan dengan cara: a). membuat sinergi dengan sekolah/lembaga untuk menyusun paket agroedutourism yang sesuai dengan latar belakang wisatawan yang bervariasi, b). melakukan kerja sama dengan petani dalam hal penggunaan sawah padi untuk lokasi agroedutourism, c). melakukan pelatihan pertanian padi organik pada petani, d). mengintegrasikan agroedutourism pada kegiatan Pendidikan formal.

Agroeduwisata inidinilai darigabungan dari dua konsep yaitu agrowisata dan edukasi. Agrowisata merupakan istilah dari wisata pertanian dengan serangkaian aktivitas dalam memanfaatkan lokasi atau sektor pertanian. Edukasi merupakan aktivitas dalam pengembangan pengetahuan, pemahaman dan pengalaman.

Seperti halnya penelitian Kuswardani et al. (2013) gambaran wilayah yang potensial ini sangat penting dalam pengembangan suatu kawasan agrotechnopark didasarkan pada potensi sumberdaya yang tersedia secara fisik, finansial dan program pembangunan wilayah yang terkait dengan pengembangan sektor pertanian, peternakan dan perikanan. Kelompok tani/Kelompok wanita tani, kelompok pembudidaya merupakan wadah belajar, pengembangan usaha, dan kerjaasama, diperlukan upaya peningkatan kedinamisan kelompok untuk dapat menjadi organisasi atau asosiasi yang kuat dalam agribisnis pertanian, perikanan, dan pemeliharaan lingkungan.

Begitu pula potensi agroedutourism pada empat lokasi penelitian ini juga didasarkan pada potensi sumberdaya yang tersedia secara fisik, finansial dan program pembangunan wilayah yang terkait dengan pengembangan sektor pertanian. Penilaian mayoritas responden terhadap agro-eduwisata menyatakan setuju tentang pembangunan desa menjadi agroeduwisata, namun masih memerlukan persiapan dalam membangun agro-eduwisata (Tabel 4).

Tabel 4. Penilaian responden terhadap agroeduwisata oleh masyarakat

\begin{tabular}{llcc}
\hline No & Indikator penilaian & & \\
. & & Jumlah & Persentase \\
\hline 1. & Tidak setuju & 3 & 1.5 \\
2. & Kurang setuju & 12 & 6.0 \\
3. & Setuju & 18 & 9.0 \\
4. & Perlu persiapan & 84 & 41.8 \\
\hline
\end{tabular}

Program Agroeduwisata di keempat lokasi penelitian yang perlu disiapkan sebagai implementasi pertanian berkelanjutan diantaranya:

1. Desa Benteng

Potensi pengolahan lebih lanjut hasil pengolahan ubi, dan kerjasama PKK, LPM dan kelompok tani/kelompok tani disinergikan dengan wisata Gunung kapur.

2. Desa Purwasari

Potensi penyiapan lokasi agroeduwisata bagi sekolah-sekolah untuk lebih dekat dengan pertanian padi, budidaya ikan dan budidaya hortikultura.

3. Kelurahan Situgede

Perbaikan dan pengembangan lokasi wisata Danau Situgede dan perluasan pemasaran hasil olahan produksi rumah tangga.

4. Kelurahan Cimahpar

Potensi wisata kota Bogor dan peningkatan produksi olehan rumah tangga, serta tanaman toga. 


\section{KESIMPULAN}

Hasil penelitian menunjukkan bahwa 1) mayoritas petani $(34,3 \%)$ membutuhkan penyuluhan terkait budidaya, dan 2) setiap lokasi memiliki strategi model agroeduwisata bisa diterapkan di lokasi penelitian dengan pelibatan berbagai pihak (kelompok wanita tani/gapoktan, PKK, LPM dan lain-lain).

\section{DAFTAR PUSTAKA}

Argabright K, McGuire J, King J. 2012. Extension Through a New Lens: Creativity and Innovation Now and for the Future. Journal of Extension Vol. 50 No.2.

BPS Kota Bogor. 2018. Perkembangan Kunjungan Wisatawan ke Kota Bogor 2008-2014. Bogor.

Fauziah HN, Asrisoesilaningsih E, Yanuwiadi B. 2016. Analisis Strategi Pengembangan dan Pengelolaan Agroedutourism Berkelanjutan. Jurnal Pembangunan dan Alam Lestari (J-PAL) Vol. 7 No.2.

Kuswardani RA, Simanullang ES, Siregar NS. Kusumastuti TA, Susilo B. 2018. Perkampungan Ternal Kambing: Wahana Eduwisata dan Sentra Produksi di Pedesaan (Pendekatan Ekonomi Lingkungan Berbasis Sistem Informasi Geografis). Yogyakarta: GadjahMada University Press.
Kurniasari DA, Ulum MF, Senandi JP, Cahyono, ED, Sugiyanto. 2015. Evaluasi Implementasi Program Pengembangan Kawasan Agribisnis Pengolahan dan Pemasaran Hasil Pertanian (KP3HP) di Kabupaten Malang. Prosiding Simposium Nasional Penyuluhan Pembangunan Berkelanjutan dan Kongres II PAPPI. p. 1-14.

Listiana, I. Efendi, I. Mutolib, A. dan Rahmat, A. 2019. The behavior of Extension Agents in Utilizing Information and Technology to Improve the Performance of Extension Agents in Lampung Province. Journal of Physics: Conference Series, 1155 (012004): 1-9.

Kuswardani, RA. Simanullang, ES. Siregar, NS. 2013. Kajian Pengembangan Kawasan Agrotechnopark di Sumatera Utara. Jurnal Agrica. Vo.6 No.1: 1-11.

Rival RS, Anugrag IS. 2011. Konsep dan Impelentasi Pembangunan Pertanian Berkelanjutan di Indonesia. Forum Penelitian Agro Ekonomi. Vol. 29 No.1.

Salikin A Karwan. 2003. Sistem Pertanian Berkelanjutan. Yogyakarta: Kanisius.

Yanfika, H. Listiana, I. Mutolib, A. dan Rahmat, A. 2019. Linkages between Extension Institutions and Stakeholders in the Development of Sustainable Fisheries in Lampung Province. Journal of Physics: Conference Series, 1155 (01201): 1-9. 